\title{
PENINGKATAN KAPASITAS MANAJEMEN USAHA BAGI PELAKU USAHA SEKTOR INDUSTRI UKM ROTI SEBAGAI UPAYA PENINGKATAN DAYA SAING USAHA MENUJU INDUSTRI MANDIRI
}

\author{
Dewi Sartika Nasution \\ Universitas Islam Negeri Mataram \\ dewisnasution@uinmataram.ac.id
}

\begin{abstract}
Abstrak: Mayoritas masyarakat Babakan memiliki mata pencaharian sebagai pengusaha roti. Akan tetapi pengelolaan usaha roti masih sangat sederhana dan tidak dikelola dengan sistematis dan terencana dengan baik. Di sisi lain kunci utama keberhasilan dalam mengembangkan usaha adalah pada manajemen pengelolaan usaha. Kemampuan dalam manajemen usaha yang dimiliki produsen roti di Babakan tergolong kategori kurang. Mereka masih menjalankan usaha sebagai pekerjaan sampingan sebagai ibu rumah tangga. Mayoritas usaha roti belum memiliki ijin edar, kemasan roti yang digunakan masih sangat sederhana dan pemasaran juga masih dalam skala lokal atau hanya di pulau Lombok saja sedangkan potensi yang dimiliki para pengusaha roti sangat besar untuk dapat memasarkan rotinya hingga ke pulau lain. Pengabdian ini bertujuan untuk meningkatkan kemampuan manajemen usaha bagi para pelaku usaha industri kecil rumah tangga di kelurahan Babakan yang terdiri dari 25 produsen roti. Pelatihan dan pendampingan melibatkan dinas kesehatan, motivator dari area capacity to grow Bank BTPN, pemuka agama, dan UIN Mataram. Pelatihan dan pendampingan adalah berkaitan dengan cara pengurusan SPP-PIRT, manajemen keuangan usaha mikro, produk halal, dan cara berbisnis islami.
\end{abstract}

Kata Kunci: UMKM, PIRT, keuangan UMKM, produk halal, produsen, bisnis islami

\begin{abstract}
The majority of the Babakan residents make a living as bread entrepreneurs. However, the management of bread business is still very simple and not managed systematically and well planned. On the other hand, the main key to success in developing a business is the ability of management. The ability in business management by bread producers in Babakan is categorized as low. They still run businesses as a side job. The majority of bread businesses do not yet have marketing licenses, bread packaging used is still very simple and marketing is also still on a local scale or only on the island of Lombok while the potential of bakers is very large to be able to market their bread to other islands. This community service program aims to improve business management ability for small-scale household industry in the Babakan subdistrict consisting of 25 bread producers. Training and mentoring involved the health office, a motivator BTPN Banks, religious leaders, and UIN Mataram team. Training and mentoring are related to the way of arranging SPP-PIRT, micro business financial management, halal products, and ways of doing Islamic business.
\end{abstract}

Keywords: UMKM, PIRT, UMKM finance, halal products, producers and Islamic businesses

\section{Pendahuluan}

Tingginya populasi usia produktif di Indonesia yang tak berbanding lurus dengan ketersediaan jumlah lapangan pekerjaan, mendorong orang Indonesia berlomba-lomba menciptakan terobosan untuk meningkatkan daya saing demi memajukan perekonomian masing-masing. Tidak heran semakin banyak bermunculan pelaku usaha sektor industri Usaha Kecil Menengah (UKM). Sektor UMKM mempunyai peran yang sangat strategis bagi pertumbuhan Ekonomi di Indonesia. Berikut data yang menunjukkan pertumbuhan jumlah UMKM di Indonesia hingga 2013. 
Tabel 1. Data UMKM di Indonesia ${ }^{1}$

\begin{tabular}{clcc}
\hline No. & \multicolumn{1}{c}{ Indikator } & Satuan & $\mathbf{2 0 1 3}$ \\
\hline 1 & Jumlah UMKM & Unit & 57895721 \\
2 & Pertumbuhan Jumlah UMKM & Persen & 2,41 \\
3 & Jumlah Tenaga Kerja UMKM & Orang & 114144082 \\
4 & Pertumbuhan Jumlah Tenaga Kerja UMKM & Persen & 6,03 \\
5 & Sumbangan PDB UMKM (harga konstan) & Rp. Miliar & 1536918,80 \\
6 & Pertumbuhan sumbangan PDB UMKM & Persen & 5,89 \\
7 & Nilai Ekspor UMKM & Rp. Miliar & 182112,70 \\
8 & Pertumbuhan Nilai Ekspor UMKM & Persen & 9,29 \\
\hline
\end{tabular}

Menurut Abdul Kadir Damanik selaku Staf Ahli Menteri KUKM bidang Penerapan Nilai Dasar Koperasi menyebutkan di tahun 2016 diperkirakan jumlah pelaku UMKM terus bertambah. Selama ini UMKM telah memberikan kontribusi pada PBD 58,92\% dan penyerapan tenaga kerja 97,30\%. ${ }^{2}$ Bahkan, berdasarkan survei HSBC pada 2009 lalu, di tengah krisis finansial, sektor UMKM justru mencatat pertumbuhan yang baik. Dalam survei tersebut dinyatakan bahwa indeks kepercayaan UMKM di Indonesia masih di atas rata-rata. Indeks kepercayaan sektor ini masih berada di angka 101 poin atau satu tingkat di atas indeks netral sebesar 100 poin. Hal ini membuat UMKM menjadi level usaha yang paling banyak mendominasi dunia usaha di Indonesia, dan semakin mengukuhkan kekuatannya terhadap krisis. $^{3}$

Di balik kontribusi UMKM yang cukup baik terhadap perekonomian nasional, ternyata sektor ini masih menyimpan segudang permasalahan yang sangat mendasar. UMKM, masih lemah dalam kemampuan manajemen usaha, kualitas sumber daya manusia (SDM) yang masih terbatas, serta lemahnya akses ke lembaga keuangan, khususnya perbankan. ${ }^{4}$ Pernyataan ini mendukung penelitian terdahulu oleh Urata yang mengatakan bahwa di antara permasalahan pokok yang dihadapi oleh UMKM adalah banyaknya UMKM yang belum bankable, baik disebabkan oleh belum adanya manajemen keuangan yang transpran maupun kurangnya kemampuan manajerial dan finansial. ${ }^{5}$ Sebagai upaya untuk meningkatkan pertumbuhan usaha kecil perlu dipelajari karakteristik serta permasalah yang dihadapi oleh UMKM. ${ }^{6}$

Glendoh dalam Trimurti menjelaskan secara umum jumlah usaha kecil sangat besar di seluruh negara namun sumbangannya terhadap nilai PDRB sangat kecil karena permasalahan yang masih melekat antara lain rata-rata tingkat pendidikan dan keterampilan pelaku usaha kecil pada umumnya rendah sehingga produktivitas dan kinerja usahanya juga rendah. ${ }^{7}$ Beberapa kendala yang dihadapi pengusaha kecil adalah keterbatasan di bidang permodalan,

\footnotetext{
${ }^{1}$ BPS diakses dari https://www.bps.go.id/linkTabelStatis/view/id/1322 pada 1 April 2017 pukul 09.30 Wita

${ }^{2}$ Anomous, Perkembangan Jumlah UMKM di Indonesia Tahun 2016 diakses dari http://www.lisubisnis.com/2016/02/perkembangan-jumlah-umkm-di-indonesia.html pada 1 April 2017 pukul 10.00 WITA

3 Wiwik Rabiatul A., Faktor Penghambat Pertumbuhan Usaha Mikro Kecil Menengah (UMKM): Studi di Kabupaten Banyumas, diakses dari http://jp.feb.unsoed.ac.id/index.php/sca-1/article/view/134/139 pada 1 April 2017 pukul 09.00

4 Adiningsih, S., (2001), Regulasi dalam Revitalisasi Usaha Kecil dan Menengah di Indonesia, http://jurnal.unikom.ac.id/vol4/art7.html, diakses tanggal 5 April 2017

${ }^{5}$ Urata Shujiro, 2000, Policy Recommendatins: Outline of tentattive Policy Recomendation for SMEPromotion in Indonesia, Publikasi JICA 17 Mei 2007

${ }^{6}$ Winarni, E.S., (2006), Strategi Pengembangan Usaha Kecil Melalu Peingkatan Aksesibilitas Kredit Perbankan, Infokop Nomor 29 Tahun XXII, pp 92-98

7 Trimurti, Model Pelatihan Kewirausahaan Berbasis Penerapan Teknologi Tenun Ikat, Jurnal Ekonomi dan Kewirausahaan, Vol. 8, No.1, April 2008, h. 96-103
} 
akses pasar, akses teknologi terapan, manajemen usaha serta kurangnya etos kerja kewirausahaan dikalangan pelaku usaha kecil. Kebanyakan orang menjalankan bisnis secara tradisional, sehingga sulit untuk berkembang. Hal ini terjadi karena ketidaktauan akan pentingnya mengelola bisnis secara profesional.

Kunci utama keberhasilan dalam mengembangkan usaha adalah pada manajemen pengelolaan usaha. Banyak usaha yang bangkrut karena pengelolaan usaha nya yang kurang bagus. Tak peduli berapa banyak modal usaha yang dimiliki lama kelamaan akan habis juga jika tidak bisa mengelola dengan baik.

Bisnis seharusnya bisa terus tumbuh dan berkembang jika ditata dengan baik dan tersistem. Akan tetapi kebanyakan pemilik bisnis hanya menjalankan bisnis sekedarnya saja tanpa arah, tujuan, dan strategi yang terencana dengan baik.

Mayoritas pemilik usaha hanya menjalankan bisnis saja, tidak membangun sistem yang menuntun langkah-langkah pelaksanaan yang pasti dalam bisnisnya, sehingga mereka harus bekerja seumur hidup agar bisnisnya tetap berjalan.

Mayoritas pelaku usaha roti di Kelurahan Babakan adalah ibu rumah tangga. Mereka memproduksi roti untuk membantu menopang perekonomian keluarga. Industri rumah tangga ini mempunyai potensi besar untuk terus dikembangkan. Permintaan pasar yang sudah ada saat ini cukup besar yaitu dari berbagai penjuru pulau Lombok. Hanya saja pengelolaan usaha roti masih sangat sederhana dan tidak terkelola dengan sistematis dan terencana dengan baik. Jika usaha roti rumah tanga dapat dikelola dengan baik maka akan berkembang menjadi industri roti yang lebih besar dan maju sehingga dapat membuka lapangan pekerjaan bukan hanya untuk masyarakat sekitar Babakan melainkan juga dapat menyerap tenaga kerja dari wilayah lain. Peningkatan perekonomian bukan hanya untuk produsen roti melainkan juga akan berimbas kepada peningkatan perekonomia masyarakat sekitar pada khususnya dan masyarakat NTB pada umumnya.

Untuk itu perlu rasanya memberikan pelatihan peningkatan manajemen usaha bagi para pelaku usaha industri kecil rumah tangga roti di kelurahan Babakan. Kelurahan Babakan terkenal dengan para pengusahanya. Mayoritas masyarakat memiliki mata pencaharian sebagai pengusaha roti, pengusaha besi tua, pengusaha mande (produk-produk alat dapur terbuat dari besi) dan pedagang. Kelurahan Babakan identik dengan roti. Reseller pasar ataupun pengecer dari berbagai daerah di Lombok membeli stok roti dari agen-agen atau pabrik roti di babakan. Pengusaha roti yang ada di kelurahan Babakan terdiri dari pengusaha roti rumah tangga hingga ke pengusaha roti yang tergolong ke dalam industri menengah dengan jumlah pekerja pabrik rotinya mencapai 50 orang lebih.

Perbandingan antara industri roti rumah tangga dengan industri roti yang tergolong ke dalam industri menengah adalah tidak signifikan. Tentunya industri roti menengah lebih maju dan memiliki modal serta manajemen usaha lebih baik dibandingkan dengan idustri rumah tangga. Jumlah pengusaha roti rumah tangga lebih banyak dibandingkan dengan pengusa roti industri menengah.

Tentu saja skill dalam manajemen usaha yang dimiliki masih dapat digolongkan ke dalam kategori kurang. Mereka masih menjalankan usaha sebagai pekerjaan sampingan sebagai ibu 
rumah tangga. Mayoritas usaha roti belum memiliki ijin edar, kemasan roti yang digunakan masih sangat sederhana dan pemasaran juga masih dalam skala lokal atau hanya di pulau Lombok saja sedangkan potensi yang dimiliki para pengusaha roti sangat besar untuk dapat memasarkan rotinya hingga ke pulau lain seperti Pulau Sumbawa bahkan Bali. Setelah melihat kondisi tersebut diatas tentunya kami berharap kondisi dari yang sebelumnya belum terbina secara baik dapat berubah sesuai dengan harapan.

Adapun tujuan diadakannya pengabdian ini antara lain meningkatnya keterampilan masyarakat dan kesejahteraan masyarakat, Terciptanya manusia yang cerdas, terampil dan beriman, meningkatkan keterampilan manajemen dan tekhnis peserta sesuai kebutuhan dan bidang usaha yang sedang dikembangkan khususnya dalam melakukan ataupun membuat pembukuan sederhana (manajemen keuangan), pemasaran dasar dan cara praktis memasarkan produk online, pengurusan ijin PIRT dan tepat kemas produk, diharapkan kelompok dampingan lebih termotivasi dan terdorong dalam hal perencanaan dan pengembangan usaha dan produktivitas. Sehingga nantinya diharapkan dengan berkembangnya usaha yang dijalankan dapat mengurangi pengangguran serta meningkatkan pendapatan kelompok dampingan, meningkatnya kesadaran wirausaha, pengetahuan dan keterampilan berusaha serta semakin kuatnya jiwa entrepreneur, peningkatan kesadaran masyarakat di desa binaan serta meningkatnya motivasi kelompok dampingan dalam meningkatkan sumber daya manusia (SDM).

Untuk mencapai efektivitas yang tinggi dalam program pelatihan dan program pembinaan manajemen usaha ini, maka akan dilibatkan berbagai pihak yaitu di perlukan keterlibatan stakeholder dan pranata masyarakat meliputi akademisi sebagai penyelenggara, penyuluh dari Dinas Kesehatan, motivator dari program-program peningkatan kapasitas manajemen usaha yang ada di Indonesia, aparatur pemerintah kelurahan babakan, para produsen dan pengusaha roti yang akan membantu suksesnya kegiatan yang akan dilakukan yang nantinya. Aparatur kelurahan dan kepala lingkungan dibantu dengan mahasiswa yang bertempat tinggal di desa / kelurahan tersebut akan membantu mengkoordinasikan dengan para pengusaha roti yang berada di ke enam lingkungan yang ada di keluarahan Babakan. Peserta penyuluhan sebanyak 30 orang terdiri dari para pengusaha roti, kue kering yang berpotensi untuk membuka usaha roti di ke enam lingkungan pada kelurahan Babakan.

\section{Metode}

Metode yang digunakan pada kegiatan pengabdian ini diantaranya dengan melakukan wawancara aparat kelurahan Babakan untuk mengumpulkan informasi mengenai potensi desa dan kondisi masyarakat desa binaan. Wawancara juga dilakukan dengan beberapa produsen roti untuk mengetahui respon mereka terhadap rancangan kegiatan pendampingan peningkatan kapasitas manajemen usaha bagi industri kecil dan menengah (IKM) Roti. Berdasarkan wawancara pada observasi awal menunjukkan reaksi yang positif dan bersedai mengikuti pelatihan jika mereka diminta sebagai peserta.

Setelah mendapatkan data yang cukup tahap selanjutnya menentukan bentuk program yang akan dijalankan. Program ditentukan berdasarkan potensi yang ada di desa/kelurahan 
tersebut dan memerlukan perhatian khusus untuk pengembangan potensi. Dimana berdasarkan informasi, tim pengabdi memilih untuk menjalankan program yang dapat menunjang pertumbuhan dan pengembangan usaha kecil mikro yang ada di desa tersebut.

Untuk memberikan edukasi yang maksimal kepada para produsen, tim pengabdi menghubungi nara sumber-narasumber yang kompeten dalam bidang yang akan disampaikan kepada produsen diantaranya narasumber dari dari Dinas Kesehatan untuk memberikan edukasi mengenai pengurusan ijin edar produk. Nara sumber lainnya adalah seorang motivator yang telah terlatih dalam memberikan pelatihan dan bimbingan untuk mengembangkan usaha mikro kecil. Motivator yang dipilih adalah motivator dari Bank BTPN dimana Bank BTPN mempunyai program pengembangan kapasitas untuk tumbuh bagi para pengusaha mikro kecil yang ada di Indonesia dan program ini telah berhasil dilakukan pada kurang lebih 800.000 pengusaha mikro di berbagai pelosok Indonesia. Narasumber lainnya adalah ahli bidang syariah islam untuk memberikan informasi berkaitan dengan bagaimana menjadi peprodusen islami dan sukses.

Kegiatan pelatihan dilakukan di kantor Kelurahan Babakan pada hari yang telah dijadwalkan. Adapun metode pelatihan dan pendapingan dalam bentuk presentasi oleh nara sumber, diskusi, studi kasus dan praktek pembuatan kas sederhana dan pemasaran online. Setelah melakukan kegiatan pelatihan selanjutnya dilakukan monitoring dan evaluasi persiapan produsen untuk pengajuan no PIRT ke Dinas Kesehatan bagi produsen roti yang belum memiliki ijin edar dan melakukan evaluasi atas pemahaman produsen dan pengusaha roti sebelum dan sesudah diberikan pelatihan. Strategi lainnya yang digunakan dengan melakukan pendampingan pengajuan ijin edar jika ada diantara produsen yang ingin mengajukan No. PIRT dan monitoring dilakukan setelah kegiatan pelatihan untuk melihat lebih dalam tingkat pemahaman dan tindakan lanjutan yang diambil oleh produsen roti setelah mendapatkan pelatihan.

\section{HASIL DAN PEMBAHASAN}

Kegiatan pelatihan dilakukan selama satu hari dan diisi oleh 3 narasumber. Hari pelatihan ditentukan setelah menyesuaikan antara waktu dari ketiga narasumber dan masa lapang mayoritas produsen di Babakan. Pelatihan awali dengan regristrasi peserta pukul 08.00. Peserta pelatihan terdiri dari masyarakat kelurahan Babakan selaku produsen roti dan kue kering. Pukul 09.30 dimulai pembukaan kegiatan dengan pembacaan kalam ilahi dan laporan kegiatan dari pengabdi selaku fasilitator dan doa. Kemudian dilanjutkan sambutan oleh kepala desa Bapak Abdul Rauf. Sambutan yang diberikan mengenai potensi dan peluang yang ada di kelurahan Babakan. Lurah juga memberikan motivasi kepada warganya untuk lebih serius dalam mengembangkan usaha UMK roti dan kue kering yang sudah ada dan segera mengurus surat ijin edar agar produk yang dihasilkan dapat dipasarkan bukan saja di pasar terdekat melainkan dapat dipasarkan hingga ke kabupaten lain bahkan ke provinsi lain.

Sesi pertama, pelatihan diberikan oleh Bapak Ahmad Suhaimi SH (pemuka agama) sebagai narasumber dan pengabdi sebagai moderator. Beliau mengisi sesi pertama dengan memberikan pencerahan dan informasi mengenai hukum syara' berkaitan dengan produk halal dan kewajiban mengkonsumsi \& memproduksi makanan halal. Sebelum masuk ke materi utama, pengabdi merasa perlu memberikan pengantar dahulu dan untuk mengingatkan kembali para 
produsen dan masyarakat bagaimana pentingnya bagi mereka untuk memperhatikan kehalalan dan kebaikan dalam memproduksi dan mengkonsumsi makanan. Pada sesi ini disampaikan materi mengenai hukum syara berkaitan dengan produk halal dan kewajiban mengkonsumsi dan memproduksi makanan yang halal.

Pada sesi kedua materi disampaikan oleh Baiq Candrayani, ST dari Dinas Kesehatan Kota Mataram. Pada sesi ke dua ini materi yang disampaikan mengenai tata cara pengajuan SPPIRT. Diantara materi yang disampaikan adalah sebagai berikut mengapa perlu ada ijin edar, bentuk sertifikat yang menunjukkan ijin edar, Siapa saja yang mengurus ijin edar, permasalahan pangan seperti higiene sanitasi tempat pengelolaan makanan, pencemaran makanan, peralatan pengelolaan makanan, penjamah makanan, keracunan pangan, produk-produk non SPP-IRT, indikator pemeriksaan sarana IRTP, bangunan dan fasilitas yang dinilai seperti ruang produksi, kelengkapan ruang produksi, tempat penyimpanan, peralatan produksi, sumber air, fasilitas dan kegiatan, pengendalian hama, kebiasaan karyawan, pekerja seperti kebersihan pekerja, pekerja sakit tidak diperbolehkan masuk, kebersihan tangan pekerja, rambut dan mulut, label pangan, alur pengurusan PIRT, alur penyelenggaraan SPP-IRT dan penerbitan SPP-IRT.

Pada sesi ini pertanyaan yang diajukan lumayan banyak. Diantara pertanyaan adalah fasilitas yang digunakan apakah harus lux, apakah boleh menggunakan ember hitam dalam memproduksi, apakah bahan makanan boleh diletakkan di lantai, apakah dapur atau tempat produksi harus luas, bagaimana dengan sistem pembuangan limbah jika lokasi produksi kecil dan dekat dengan got/saluran pembuangan, berapa lama proses dari pengajuan ijin sampai ijin dikeluarkan, apakah produk harus memiliki merk dahulu dan lain-lain. Setelah tanya-jawab selesai pada sesi ini dilanjutkan dengan latihan cara mengisi borang pengajuan ijin edar yang sudah dibagikan ke peserta.

Pada sesi ke tiga ini materi yang disampaikan Antonius Lao, SE. mengenai manajemen keuangan mikro. Diantara materi yang disampaikan adalah sebagai berikut pemahaman mengenai pendapatan dan pengeluaran. Bagaimana membedakan dan apa saja yang tergolong ke dalam keduanya, pemahaman untung dan rugi, pemahaman mengenai utang piutang, keuangan usaha dan keuangan keluarga, bagaimana cara melakukan pencatatan dan pemisahan antara uang usaha dan uang keluarga, latihan pencatatan keuangan untung dan rugi, latihan untung/rugi usaha, latihan pencatatan utang piutang, latihan pencatatan uang usaha dan uang keluarga, latihan pencatanatan pendapatan dan pengeluaran dilihat dari uang usaha dan uang keluarga, motivasi kepada para produsen untuk rajin mencatat/pembukuan sebagai langkah awal dalam mencapai keberhasilan manajemen usahanya.

Pada sosialisasi dan pelatihan ini peserta diberikan pertanyaan-pertanyaan awal sebagai pre-test oleh masing-masing narasumber secara lisan untuk mengetahui sejauh mana pengetahuan mereka mengenai ijin edar industri dan pembukuan sederhana. Pertanyaan tersebut diantaranya apakah mereka mengetahui apa itu nomor PIRT, bagaimana mengurusnya, apakah mereka sudah memiliki nomor PIRT pada produk mereka, apakah merek tau bentuk ataupun logo nomor PIRT dan dimana biasanya nomor PIRT berada pada suatu produk. Post test juga dilakukan setelah masing-masing narasumber melakukan sosialisasi. Diantara pertanyaan yang diajukan oleh narasumber adalah apakah mereka sekarang sudah 
tau bentuk ijin edar industri dan sertifikasi jaminan halal seperti apa?, apakah mereka siap setelah selesai sosialisasi langsung mengisi borang pengajuan ijin edar agar dapat dibantu untuk diproses oleh ke dua narasumber, apakah mereka berkeinginan untuk mengajukan ijin edar, apakah mereka mau untuk memperbaiki rumah produksi, produk agar sesuai dengan syaratsyarat yang ada sehingga dapat segera mengajukan ijin edar.

Evaluasi atas capaian keberhasilan kegiatan ini dapat diketahui melalui beberapa indikator diantaranya:

a. Dilakukan pre test sebelum sosialisasi diberikan untuk mengetahui tingkat pengetahuan dan kesadaran produsen dan masyarakat akan produk halal, sertifikasi halal dan ijin edar. Berdasarkan pre tes diketahui bahwa pengetahuan masyarakat akan ijin edar masih sangat minim. Peserta semua belum tau bentuk / logo PIRT, kesadaran peserta rendah mengenai ijin edar yang tertera di setiap kemasan produk, peserta tidak mengetahui cara pengajuan ijin edar, peserta merasa mengurus ijin edar dan sertifikasi halal sangat mahal, peserta merasa prosedur mendapatkan ijin edar dan sertifikasi halal sangat susah, peserta tidak mengetahui cara melakukan pembukuan sederhana dan dalam mengatur antara uang usaha dan uang keluarga/pribadi.

b. Untuk mengevaluasi daya serap dan pemahaman peserta akan materi yang disampaikan, peserta diminta untuk menjawab pertanyaan lisan sebagai post test seputar materi yang disampaikan. Berdasarkan hasil tes dapat disimpulkan peserta khususnya produsen lebih faham akan ijin edar dan cara melakukan pencatatan usaha sederhana. Sehingga dapat disimpulkan setelah sosialiasi dan pelatihan terdapat peningkatan kesadaran dan pemahaman masyarakat dan UMKM atas pengurusan ijin eder dan pembukuan sederhana.

c. Produsen ditawarkan untuk mengajukan ijin edar oleh narasumber dari Dinas Kesehatan pada saat pelatihan tetapi karena belum ada kesiapan dari para produsen tawaran dibuka tanpa batas waktu sampai mereka benar-benar siap untuk mengajukan. Narasumber menawarkan diri untuk membantu proses dan pendampingan sekiranya produsen telah siap untuk mengajukan borang ijin edar. Para produsen dapat langsung menghubungi narasumber sekiranya telah siap mengajukan nantinya. Berdasarkan pertanyaan yang diajukan ke dua narasumber diperoleh respon yang positif dari para produsen. Mereka hampir semua berkeinginan untuk mengajukan ijin edar dan mulai melakukan pencatatan dan pemisahan antara uang usaha dan uang keluarga. Hanya saja untuk pengajuan ijin edar mereka terlebih dahulu ingin melakukan perbaikan dan persiapan sesuai syarat-syarat yang dijelaskan oleh nara sumber. Untuk saat ini belum terdapat satupun produsen makanan ringan yang telah mempunyai ijin edar dari Dinas Kesehatan.

d. Monitoring pertama pengabdi dan tim turun ke lapangan untuk melihat sejauh mana persiapan produsen untuk mengajukan ijin edar. Mereka masih melakukan pembenahan di rumah produksi, cara produksi dan bahan yang digunakan serta tehnis lainnya belum dapat dibuat sesuai syarat yang telah dijelaskan ketika pelatihan dan sosialisasi oleh nara sumber dari Dinas Kesehatan Kota Mataram.

e. Pada monitoring ke dua juga masih belum ada diantara para produsen yang siap mengajukan ijin edar tetapi sudah ada yang mulai melakukan pencatatn sederhana. 
Menurut para produsen membutuhkan waktu dan biaya untuk berbenah agar dapat menyesuaikan dengan prasyarat yang ada.

f. Sampai laporan ini dibuat belum ada satupun produsen yang siap untuk didampingi mengajukan ijin edar. Mereka mengatakan akan menghubungi nara sumber atau pengabdi untuk memberikan pendampingan jika mereka telah siap untuk mengajukan ijin edar.

\section{Kesimpulan}

Mengurus ijin edar sangat diperlukan sebagai jaminan bahwa usaha makanan dan minuman rumahan yang dijual memenuhi standar keamanan makanan dan halal untuk dikonsumsi. Usaha produksi roti digeluti oleh sekitar ratusan pengusaha yang tersebar di Kelurahan Babakan. Masyarakat yang memiliki usaha pengolahan pangan (roti) tidak memiliki pengetahuan dan pengalaman yang cukup mengenai ijin edar dan pembukuan sederhana.

Salah satu keluhan masyarakat dan masalah yang dihadapi berdasarkan wawancara pada observasi awal adalah masyarakat yang memiliki usaha roti ingin memperoleh pendampingan dan pencerahan mengenai ijin edar produk bagi produk mereka. Untuk itu pendampingan, pelatihan dan sosialisasi kepada para pengusaha makanan ringan di desa tersebut mengenai cara pengurusan ijin edar dari Dinas Kesehatan dan cara pembukuan sebagai dukungan untuk manajemen usaha yang baik.

Kegiatan pelatihan berlangsung selama 1 hari penuh dan dilanjutkan dengan pendampingan, monitoring dan evaluasi. Hanya saja untuk proses pendampingan tidak dapat dilakukan karena semua produsen belum siap untuk mengajukan permohonan pengurusan ijin edar dan sertifikasi halal. Salah satu faktor yang menghalangi adalah kondisi rumah produksi, pekerja dan produk belum sesuai dengan syarat minimal yang harus dipenuhi oleh produsen ketika ingin mengajukan ijin edar.

\section{Referensi}

Adiningsih, S., (2001), Regulasi dalam Revitalisasi Usaha Kecil dan Menengah di Indonesia, http://jurnal.unikom.ac.id/vol4/art7.html diakses tanggal 5 April 2017

Anomous, Perkembangan Jumlah UMKM di Indonesia Tahun 2016 diakses dari http://www.lisubisnis.com/2016/02/perkembangan-jumlah-umkm-di-indonesia.html pada 1 April 2017 pukul 10.00 WITA

BPS diakses dari https://www.bps.go.id/linkTabelStatis/view/id/1322 pada 1 April 2017 pukul 09.30 Wita

Trimurti, Model Pelatihan Kewirausahaan Berbasis Penerapan Teknologi Tenun Ikat, Jurnal Ekonomi dan Kewirausahaan, Vol. 8, No.1, April 2008, 96-103

Urata Shujiro, 2000, Policy Recommendatins: Outline of tentattive Policy Recomendation for SMEPromotion in Indonesia, Publikasi JICA 17 Mei 2007

Winarni, E.S., (2006). Strategi Pengembangan Usaha Kecil Melalu Peingkatan Aksesibilitas Kredit Perbankan, Infokop Nomor 29 Tahun XXII, pp 92-98

Wiwik Rabiatul A., Faktor Penghambat Pertumbuhan Usaha Mikro Kecil Menengah (UMKM): Studi di Kabupaten Banyumas, diakses dari http://jp.feb.unsoed.ac.id/index.php/sca1/article/view/134/139 pada 1 April 2017 pukul 09.00 